\title{
Total factor productivity drivers in the selected EU countries: Cointegration approach*
}

\author{
Zoran Borović ${ }^{1}$, Mladen Rebic ${ }^{2}$, Dalibor Tomaš $\breve{s}^{3}$
}

\begin{abstract}
In this paper, we will present the results of our survey on TFP and its main drivers. For this purpose, our analysis is based on a sample of thirteen EU countries for the period 1995 - 2016. In the first iteration, we have estimated the TFP for selected countries. The main goal of this paper is to determine the existence of a long-run relationship, ie. cointegration between the TFP and its main drivers. To do so, in the second iteration we have used the relatively new panel ARDL (Autoregressive Distributed Lag) model proposed by Pesaran (1997) and Pesaran and Shin (1999). The obtained results in this paper reveal the existence of a longterm relationship, i.e. co-integration between the TFP on one hand, and $R \& D$, and ICT, on the other hand, confirming the basic hypothesis that there is a long-term and statistically significant relationship, i.e. co-integration between the abovementioned variables.
\end{abstract}

Key words: growth, total factor productivity, foreign direct investment, research and development, information and communication technologies, Cobb-Douglas production function, cointegration

JEL classification: F20, F21, F23

\footnotetext{
* Received: 14-05-2019; accepted: 26-03-2020

1 Assistant professor, Faculty of Economics, University of Banja Luka, Majke Jugovića 4, 78000 Banja Luka, BiH. Scientific affiliation: Theoretical economics. Phone: +387 51430 010; Fax: +38751430 053.E-mail: zoran.borovic@ef.unibl.org.

${ }^{2}$ Associate professor, Faculty of Economics, University of East Sarajevo, Alekse Šantića 3, 71420 Pale, BiH. Scientific affiliation: theoretical economics. Phone: +38757226 651; Fax: +38757 226 188.E-mail: rebicmladen@yahoo.co.uk.

3 Senior Assistant, Faculty of Economics, University of Banja Luka. Majke Jugovića 4, 78000 Banja Luka, BiH. Scientific affiliation: theoretical economics. Phone: +387 51430 010; Fax: +38751430053.E-mail: dalibor.tomas@ef.unibl.org.
} 


\section{Introduction}

Total Factor Productivity (hereinafter TFP) is one of the most celebrated residuals in economic science. It represents the growth in output after taking into account the growth contributions from inputs. Academics have spent hours, and hours on conceptualizing, measuring and interpreting TFP. The concept of TFP has been very intriguing for policymakers. The policymakers have spent a lot of effort to understand how policies might positively impact on a country's TFP.

Through the history, the academics, scientist, and policymakers were obsessed with TFP, its measuring, and interpretation. Why were they so obsessed with TFP? Because productivity is the only sustainable source of long-term economic growth and without it, the entire economy will start to slow down. The only factor which does not suffer from diminishing returns as other homogeneous inputs typically do is the TFP.

The TFP is of great importance for state economic growth. Even if its contribution is relatively small, compared to labour or investment as growth drivers, small annual improvements do add up over longer periods of time. The TFP is considered to be a main driving force behind the sustainable long-term growth. If TFP slows down, in long-term, it will cause the economy's inability to generate growth or prevent a decline. Therefore, the TFP and its slowdown is a matter of major concern in Europe, and recently in the USA and in several emerging market economies.

The models, based on a standard neoclassical growth framework, do not appear to be consistent with recent facts regarding the EU's growth performance. Recent growth theories, based on "Schumpeterian" creative destruction mechanisms are more likely to interpret recent developments in the EU's growth performance than standard neoclassical growth theories. This theory focuses on innovation as the key driver of growth in economies at, or close to, the "technology frontier (Havik, et al., 2008. p. 5). The rate of innovation and the rate at which "state-of-the-art" technologies are adopted are the two main driving forces behind the countries economic growth in theories, based on "Schumpeterian" creative destruction mechanisms. Countries that are close to the technology frontier will mainly grow thanks to the introduction of new technologies, whilst the "follower" grouping of countries will derive the largest share of their TFP growth from the adoption of better, but already existing, technologies which are available "at the frontier" (Havik, et al., 2008. p. 5). Beside innovations as the key driver of growth, there are some newly added factors which have been identified as additional drivers of productivity: Foreign Direct Investment (FDI), Information and Communication Technologies (ICT), Research and Development (R\&D), and trade openess.

Many researches use a different panel technique to estimate the TFP on a sectoral level and to investigate the impact of productivity drivers on the TFP for different periods and on different samples. Some of them use an EU KLEMS database as 
a source for data. Our goal is twofold. First, to calculate the TFP for the $10 \mathrm{EU}$ countries by applying growth accounting. Second, we aim to investigate the longterm impact of productivity drivers on the TFP, for the selected countries, by using the cointegrating technique.

In this paper we will estimate the TFP over several years and focus our analysis on a rich set of TFP drivers: Foreign Direct Investment (FDI), Information and Communication Technologies (ICT), Research and development (R\&D), human capital (h), and trade openness (OPP). We will conduct our analysis on the following EU countries: Austria, Belgium, Denmark, Finland, France, Germany, Greece, Ireland, Italy, the Netherlands, Portugal, Spain, Sweden, and the United Kingdom. At this time, the UK is still a fully member of the EU. The basic hypothesis of this paper is that there is a long-term and statistically significant relationship, i.e. co-integration between the TFP and its main drivers: Foreign Direct Investment, trade openess, Information and Communication Technologies, Research and Development, and human capital. The obtained results in this paper reveal the presence of co-integration between the TFP and its main drivers.

This paper is organized in the following manner. Section 2 discusses the existing literature and gives some theoretical background. Section 3 provides information on data, model specification and appliedmethodology. Section 4 presents empirical results and discussion. Section 5 concludes the paper.

\section{Literature review}

Total Factor Productivity (TFP) is the portion of output not explained by the amount of inputs used in production (Comin, 2008). According to Sahu \& Narayanan (2011), the TFP measures the effects of technological change and increases in efficiency over long periods of time, and it is estimated as a residual from the production function. On the other hand, the TFP measures only externalities and other free gifts associated with economic growth (Griliches, 2007). The TFP can be considered as a measure of our ignorance, it is simply a measure of what we do not know (Abramovitz, 1956). The TFP is labelled as a measure of ignorance, because there is little known about this non-input, very often unobservabledeterminants of economic growth.

Summarizing all the previous quotes and definitions, it is clear that TFP means different things to different authors. The different authors have a different stand regarding a TFP, and their views of TFP are summarized in the following paragraphs (Lipsey, et al., 2001. p. 3):

- One group holds that changes in TFP measure the rate of technical change (Law, Krugman, Young). We refer to this as the "conventional view"; 
- The second group holds that TFP measures only the free lunches of technical change, which are mainly associated with externalities and scale effects (Jorgenson, and Griliches). We refer to their position as the "J\&G view";

- The third group is sceptical that TFP measures anything useful (Metcalf, and Griliches).

Our position is close to the "conventional view".

For a sustainable, and long-term growth, productivity improvements, based on technological progress, and human capital accumulation are of great importance. The endogenous growth models, by Romer (1990), Rivera-Batiz and Romer (1991), Grossman and Helpman (1991), and Aghion and Howitt (1992, 1998), are innovation-based and build upon the contribution of R\&D. Romer (1988) and Lucas (1998) have been analyzing the role of human capital in speeding up economic growth, within the framework of the endogenous growth theory. Human capital can have both direct and indirect effect on economic growth. On one hand, the human capital has a direct effect on growth since it enters the production function. On the other hand, the human capital is strictly complementary with R\&D activities in speeding up productivity growth (Autor et al. 1998; Berman et al. 1998; Borensztein et al. 1998; Redding 1996).

Gehringer, et al. (2014) conducted a survey based on 17 Eastern European countries for the period 1995-2007, and the main results show that TFP variation is mainly explained by factors common to all countries: human capital, trade openness, rationalization efforts, and the use of information and communication technologies. They have used heterogeneous production functions, based on a value-added approach on a sectoral level. The estimation of the TFP and investigation of the TFP determinants is carried out by augmented mean group estimator. If the analysed countries aim at improving TFP and therefore, their economic performance in the global economy, they should favour specific policies that enhance human capital formation, widen the use of ICTs and control labour costs.

The available empirical specifications normally reflect areduced form of the basic innovation-imitation model, with most of them regressing TFP growth on two key explanatory variables (Havik, et al., 2008. p. 6):

- a measure of the technology gap (i.e. the distance between the TFP of the country analysed and that of the country with the highest level of efficiency); and

- an estimate of the growth rate of TFP at the frontier (i.e. the TFP growth rate of the most efficient country).

The measure of the technology gap describes the impact of the adoption of more efficient existing technologies on the TFP growth. The second variable 
describes the impact of innovation and knowledge spillovers which are taking place in the technologically most advanced country on the TFP growth in the "catching up" country. In most papers, authors in addition to the above basic explanatory variables include a policy and institutional factors that may affect the rate of TFP growth independently. These policy and institutional factors may also interact with the "technology gap" and "technology spillovers" variables to have an impact on TFP. More recently, additional factors, have been identified as additional drivers of productivity. These newly added factors are Foreign Direct Investment (FDI), Information and Communication Technologies (ICT), R\&D, and trade.

The sectoral TFP growth in a panel of OECD countries was analyzed by Nicoletti and Scarpetta (2003). The further away are countries from the technology frontier, this impact becomes stronger. The adoption of existing up-to-date technologies are prevented mainly by entry regulation and by public ownership, and because of this prevention, the impact of TFP is greater away from the frontier. Away from the frontier, the TFP growth is more strongly based on adoption rather than on innovation. The same study shows that human capital has a positive impact on TFP growth, although not always significant.

A study on TFP determinants across sectors in a panel of OECD countries was performed by Griffith, Redding and Van Reenen (2004). The authors have stressed the importance of both the direct and indirect impact of R\&D on productivity growth. The R\&D has a direct impact on the TFP growth rate through enhancement of a firm's innovative potential. The indirect impact of R\&D on the TFP growth rate is achieved by increasing the absorptive capacity of firms and industries, thus facilitating the adoption of existing technologies and spurring TFP convergence.

The role of quality of human capital (QHC) as a determinant of productivity growth for ' 'new' and 'old' EU members was investigated by Balcerzak and Pietrzak (2016; 2016a). In order to measure the QHC and to obtain the time series, they have used a TOPSIS method. To investigate the impact of the QHC on the TFP growth, for both 'new' and 'old' EU members, the dynamic panel model was applied. Their results confirm the positive influence of the QHC on TFP for both 'new' and 'old' EU members.

\section{Model specification and methodology}

The first step in our analysis is to estimate the TFP levels over time and across countries. In our analysis, we will apply the Cobb-Douglas production function. We can apply the Cobb-Douglas production function because we consider the analysed countries to be very homogenous in relation to structural and institutional factors 
affecting productivity ${ }^{4}$. The standard Cobb-Douglas production function can be written as:

$$
Y=A K^{\alpha} L^{\beta}
$$

Where Y represents output or real GDP, the K stands for the economy-wide capital stock, $\mathrm{L}$ represents employment, and $\alpha+\beta=1$. The $\mathrm{A}$ is interpreted as the TFP.

There are many empirical approaches to evaluate the TFP in modern literature (see. Welfe (ed.) 2007; Severgnini and Burda, 2010, pp. 447-466; Gehringer et al., 2014). To obtain the TFP we will use the growth accounting, which basics were presented in Solow (1956 and 1957.). The main assumptions of the Solow growth model are competitive markets and constant returns to scale. With some rearrangements, we can rewrite the standard Cobb-Douglas production function as:

$$
\Delta \log Y=\Delta \log A+\alpha \Delta \log K+\beta \Delta \log L
$$

The TFP, as a rate of the technological progress, can be calculated as a residual from the equation (2). The parameters $\alpha$ and $\beta$ are the factors marginal (social) products. These parameters are defined as:

$$
\begin{aligned}
& \alpha=\frac{\partial Y}{\partial K} \frac{K}{Y} \\
& \beta=\frac{\partial Y}{\partial L} \frac{L}{Y}
\end{aligned}
$$

In practice, we assume that factors are paid their full marginal products so that $\alpha$ and $\beta$ represents the share of capital and labour in the realized GDP.

The labor share $\beta$ indicates how much of national income is distributed to labor and how much to capital. There are several ways to calculate the share of labour $\beta$. Batini, et al, (2000) suggests that the share of labor can be calculated as:

$$
\beta=\frac{W N}{P Y}
$$

Where $\mathrm{W}$ is labour cost per employee, $\mathrm{N}$ is employment, $\mathrm{P}$ is the GDP deflator at factor cost, and Y is national income. US Bureau of Labor Statistics calculates the labour share as ${ }^{5}$ :

\footnotetext{
4 According to Balcerzak and Pietrzak (2016a), countries which have joined the EU before 2004. can be considered as very homogenous in relation to structural and institutional factors affecting productivity

5 https://www.bls.gov/opub/mlr/2017/article/estimating-the-us-labor-share.htm
} 


$$
\beta=\frac{E C+P C}{O}
$$

Where EC stands employee compensation, PC stands for proprietors labour compensation, and $\mathrm{O}$ stands for Output. According to Ganev (2005) the labour share is calculated as:

$$
\beta=\frac{C O E+N M I}{G D P}
$$

Where COE is the compensation of employees, and NMI is the net mixed income. In our survey, we will use the Compensation of employees as a percentage of GDP, published by EUROSTAT, as a proxy for labour share. Compensation of employees is defined as the total remuneration, in cash or in kind, payable by an employer to an employee in return for work done by the latter during the accounting period and it is consists of wages and salaries, and of employers' social contributions ${ }^{6}$.

We will use the equation (2) to calculate the TFP, and after we calculate the TFP over time and across countries, we will use the predicted TFP to estimate the productivity drivers in the selected countries.

\subsection{The Capital stock}

The data on capital stock are very often provided by the official statistics office. But, statistical offices from different countries can use a different method to obtain capital stock. The perpetual inventory method is the most common method, used in many studies for assessiment of capital volume, and it can be described with equation:

$$
K_{t}=I_{t}+(1-\delta) K_{t-1}
$$

Where $\delta$ represents the depreciation rate and I stands for investments. The subscript $\mathrm{t}$ stands for the beginning of the time period $\mathrm{t}$ and $\mathrm{t}-1$ represent the previous time period. All other variables have the same meaning as in expression (1). Our nex step is to assess the anchor capital stock. There are four methods for the assessment of the anchor capital stock. First method assumes the steady state of the economy. If we assume the stady state of the economy, then the anchor capital volume will grew at a constant rate $\sigma$. The initial capital, or anchor capital is estimated with following equation:

$$
K_{0}=\frac{I_{0}}{\sigma+\delta}
$$

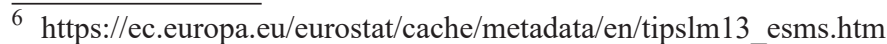


Where $\mathrm{K}_{0}$ is the initial capital stock, $\mathrm{I}_{0}$ are investments in the anchor period, and other variables have the same meaning as in previous equations. The main problem with this method is the estimation of the steady-state growth rate of the capital. The steady-state growth rate of the capital can be obtained in different ways. One way is to use a growth rate of the investments as a proxy for the steady-state growth rate of the capital (De la Fuente and Doménech, 2006; Berlemann and Wesselhöft, 2014). The other way is to use the growth rate of output as a proxy for the steady-state growth rate of the capital. In the steady-state, the output and capital grow at the same rate, thus, we can use the growth rate of output as a proxy for the steady-state growth rate of the capital (Harberger, 1988). In this case, it would be necessary to remove all shocks to the growth rate of the capital and output, which can be done by smoothening the series with a Hodric-Prescot filter with $\lambda=100$. The steadystate growth rate of the capital can be obtained by regressing the log investment on time (Berlemann and Wesselhöft, 2014).

The second method is similar to the previous one. The initial capital stock is calculated by dividing the real fixed investment in the first period $\mathrm{I}_{0}$ with depreciation rate $\delta$ (Ganev, 2005a and 2005b):

$$
K_{0}=\frac{I_{0}}{\delta}
$$

The third method for the initial capital calculation is to divide the product of GDP in anchor year and average investment rate for the entire period with the sum of the average growth rate of the GDP and depreciation rate $\delta$ (Easterly and Levine, 2001):

$$
K_{0}=\frac{Y_{0} \sum_{0}^{t(I / Y)} \frac{\Delta}{T}}{\sum_{0}^{t} \frac{\Delta Y}{\mathrm{Y}}+\delta}
$$

The fourth method for the initial capital calculation requires dividing the real fixed investment in the first period $\mathrm{I}_{0}$ with the sum of the average growth rate of the investments and depreciation rate $\delta$ (Kyriacou, 1991):

$$
K_{0}=\frac{I_{0}}{\sum_{0}^{t} \frac{\Delta I}{I}+\delta}
$$

We can rewrite the equation (5) and get geometric depreciation method:

$$
K_{t}=(1-\delta)^{t} K_{0}+\sum_{i=0}^{t-1}(1-\delta)^{i} I_{t-i}
$$

The expression (5) implies that some part of the capital stock will have eternal life, i.e. the amortized value of initial capital will never be equal to zero. Our survey requires that capital has to have a finite life, i.e. it will depreciate entirely for a finite number of years. For this reason, we will use a linear depreciation method: 


$$
K_{t}=(1-t \delta) K_{0}+\sum_{i=0}^{t-1}(1-t \delta) I_{t-i}
$$

The linear depreciation method will enable a linear reduction of the initial capital, and the value of investments that are made between the initial and the present moment. In this way, the capital stock will be a fully depreciated for $1 / \delta$ periods. The current capital stock is the weighted sum of initial capital value, $\mathrm{K}_{0}$, and intervening investment expenditures, with weights corresponding to their undepreciated components (Burda, et al., 2008).

For the purpose of our analysis, we will use the expression (9) to estimate the initial capital stock, and linear depreciation method to obtain the current capital stock.

For calculating capital stock in the initial period and for estimating the capital stock from period to period, the depreciation rate is of great importance. Here, we assume that the depreciation rate is constant over the period and across countries. We set the depreciation rate at 0.05 . In many studies and papers in literature the depreciation rate is set within the range between 0.04 and 0.10 (Vanags and Bems 2005; Griliches, 1980; Nehru and Dhareshwar, 1993; Romer, 1988; Kamps, 2006; Berlemann and Wesselhöft, 2014; Harberger, 1988; Nadiri and Prucha, 1996). The depreciation rate at 0.05 is used by De la Fuente and Doménech (2006), Hernandez and Mauleon (2003) for the economy of Spain, Cororaton (2002) for the Philippines, and Felipe (1997) for a group of countries in East Asia.

\section{Empirical data and analysis}

We will conduct our analysis on following EU countries for the time period 19952016: Austria (Aus), Belgium (Bel), Denmark (Den), Finland (Fin), France (Fra), Germany (Ger), Grece (Gre), Ireland (Ire), Italy (Ita), Netherlands (Net), Portugal (Por), Spain (Spa), Sweden (Swe), and United Kingdom (UK). Variables, their definition and sources are presented in Table 1. 
Table 1: Variables description

\begin{tabular}{|c|c|c|}
\hline Variable & Description & Source \\
\hline Y & $\begin{array}{l}\text { GDP, the chain linked volumes (2005), } \\
\text { in millions of euros }\end{array}$ & EUROSTAT \\
\hline $\mathrm{y}$ & GDP per employee & Authors calculation \\
\hline I & $\begin{array}{l}\text { Gross fixed capital formation, the chain } \\
\text { linked volumes (2005), in millions of euros }\end{array}$ & EUROSTAT \\
\hline K & Capital stock & Authors calculation \\
\hline $\mathrm{k}$ & Capital/labor ratio & Authors calculation \\
\hline $\mathrm{L}$ & $\begin{array}{l}\text { Employment type: Harmonized ILO } \\
\text { definition (in millions) }\end{array}$ & World Economic Outlook Database, \\
\hline$\alpha$ & Capital share as a percentage of GDP & Authors calculation \\
\hline$\beta$ & $\begin{array}{l}\text { Labor share: Compensation of employees as } \\
\text { a percentage of GDP }\end{array}$ & EUROSTAT \\
\hline TFP & Total Factor Productivity & Authors calculation \\
\hline $\mathrm{R} \& \mathrm{D}$ & $\begin{array}{l}\text { Gross domestic expenditure on R\&D as a } \\
\% \text { of GDP }\end{array}$ & EUROSTAT \\
\hline OPP & $\begin{array}{l}\text { Calculated as a sum of export and import as } \\
\text { a percentage of GDP }\end{array}$ & $\begin{array}{l}\text { World Bank national accounts data, and } \\
\text { OECD National Accounts data files. }\end{array}$ \\
\hline FDI & $\begin{array}{l}\text { Foreign direct investment, net inflows } \\
(\% \text { of GDP) }\end{array}$ & $\begin{array}{l}\text { World Bank national accounts data, and } \\
\text { OECD National Accounts data files. }\end{array}$ \\
\hline $\mathrm{h}$ & $\begin{array}{l}\text { human capital investment rate -as proxied } \\
\text { by secondary enrolment rate }\end{array}$ & $\begin{array}{l}\text { World Bank national accounts data, and } \\
\text { OECD National Accounts data files. }\end{array}$ \\
\hline ICT & ICT/non ICT real capital stock ratio & EUROSTAT \\
\hline
\end{tabular}

We have transformed the data regarding the FDI because some observation for the FDI are negative. The transformation was necessary, because, in our analysis, we use the data in their logarithmic form. The transformation was carried out using the following procedure (Busse and Hefeker, 2007; Ren, et al., 2012):

$$
Y=\log \left(x+\sqrt{x^{2}+1}\right)
$$

Where $\mathrm{Y}$ is the transformed value of FDI and $\mathrm{x}$ stands for the initial value of the FDI. We have assessed the capital stock and anchor capital by applying the equations (9) and (14) on investment data. The Belgium is excluded from further analysis due to objective lack of data.

We have calculated the TFP by applying the equation (2). The average value of $\alpha$ is approximately 0.54 , and the average value of $\beta$ is approximately 0.459 . The descriptive statistics for TFP, R\&D, ICT, FDI, human capital, and openness are presented in Table 2. 
Table 2: Descriptive statistics for TFP, R\&D, ICT, FDI, and openness (in logs)

\begin{tabular}{|l|c|c|c|c|c|c|}
\hline & TFP & OPP & ICT & R\&D & FDI & $\mathrm{h}$ \\
\hline Mean & 1.372474 & 4.303829 & -3.399300 & 0.523463 & 1.639568 & 4.698559 \\
\hline Maximum & 1.895809 & 5.398877 & -2.659260 & 1.363537 & 5.164162 & 5.053384 \\
\hline Minimum & 0.3496219 & 3.613829 & -4.605170 & -0.867501 & -2.733828 & 4.475193 \\
\hline Std. Dev. & 0.3465166 & 0.376657 & 0.313432 & 0.504795 & 1.283988 & 0.1165512 \\
\hline Observations & 286 & 286 & 267 & 278 & 285 & 278 \\
\hline
\end{tabular}

Source: Authors calculation

One of the assumptions of the classic OLS requires that explanatory variables are not linearly correlated. The presence of an exact linear correlation between the explanatory variables indicates the problem of multicollinearity. In our case there is no multicollinearity, i.e. there is a very small level of correlation between the explanatory variables. The correlation matrix shows the absence of a linear correlation between the explanatory variables.

Table 3: Correlation matrix (in logs)

\begin{tabular}{|c|c|c|c|c|c|}
\hline & FDI & OPP & ICT & R\&D & $\mathrm{h}$ \\
\hline FDI & 1.0000 & & & & \\
\hline OPP & 0.3977 & 1.0000 & & & \\
\hline ICT & -0.0160 & -0.1192 & 1.0000 & & \\
\hline RD & 0.016 & 0.292 & 0.0603 & 1.0000 & \\
\hline H & 0.2471 & 0.3563 & 0.1339 & 0.3483 & 1.0000 \\
\hline
\end{tabular}

Source: Authors calculation

We continue our analysis with an assessment of the effect of the productivity drivers on the TFP. First, we will test the time series for stationarity. Testing the series of data for stationarity is necessary for two reasons. First, if we apply the static panel on the variables which follow the unit root process, we will have a spurious regression as a result. Second, testing variables for the order of integration will help us to choose an appropriate model for panel analysis. Testing variables for the order of integration was carried out by Im, Pesaran, and Shin test (IPS). The results for unit root tests are presented in Table 4. The detailed results for unit root tests are in the appendix. 
Table 4: Unit root test for TFP, R\&D, ICT, FDI, human capital, and oppenes (in $\operatorname{logs})$

\begin{tabular}{|c|c|c|c|}
\hline Variable & Level & 1st difference & $\mathrm{I}(\mathrm{d})$ \\
\hline TFP & No unit root & & $\mathrm{I}(0)$ \\
\hline R\&D & Unit root & No unit root & $\mathrm{I}(1)$ \\
\hline ICT & Unit root & No unit root & $\mathrm{I}(1)$ \\
\hline FDI & No unit root & & $\mathrm{I}(0)$ \\
\hline Openness & No unit root & & $\mathrm{I}(0)$ \\
\hline $\mathrm{h}$ & Unit root & No unit root & $\mathrm{I}(1)$ \\
\hline
\end{tabular}

Source: Authors calculation

Our goal here is to determine the existence of co-integration between the TFP, on one hand, and the productivity drivers, on the other hand. Because our series does not have the same level of integration, the use of standard co-integration tests are not allowed. Here, we will rely on the results of the relatively new panel ARDL (Autoregressive Distributed Lag) model proposed by Pesaran (1997) and Pesaran and Shin (1999). This model will provide a consistent and effective estimation of both long-and short -term effects, on the basis of panel data series with a different level of integration, lower than I (2), which includes a relatively large number of observation units and time. The ARDL model includes the lagged dependent variable, and it can also include the lagged explanatory variables. The form of the dynamic ARDL (p, q) model was defined by Paseran and Shin (1990):

$$
y_{i t}=\sum_{j=1}^{p} \lambda_{i j} y_{i, t-j}+\sum_{j=0}^{q} \delta_{i j} x_{i, t-j}+\mu_{i}+\varepsilon_{i j}
$$

Where $\mathrm{i}$ represents the number of observation units $i=1,2, \ldots, \mathrm{N} ; t$ represents the number of time instances $t=1,2, \ldots, \mathrm{T} ; x_{i t}$ is vector of independent variables of dimension $k^{\prime} 1 ; \lambda_{i j}$ is coefficient of lagged dependent variable; $\mu_{i}$ is parameter that determines the specific effects of the group or observation unit.

First step in our analysis is to determine the optimal lag for Pooled Mean Group (PMG)-ADRL model. To do so, we will estimate autoregressive distributed lag (ARDL) model for each country in the panel, and then, we will determine optimal lag for each variables for that country based on the Bayesian information criteria (BIC). The optimal lag for PMG-ADRL model is selected as the most common lag for each variable. Optimal lag for all variables is set to 1 .

In addition to PMG model, we have also estimated the Mean Group (MG) model, and then, we have used the Hausman test to choose which model is more adequate. The MG estimator estimates the mean of long and short-run coefficients across countries by the unweighted average of the individual country coefficients, which 
makes him less informative than the PMG. By using an MG estimator, we cannot obtain a coefficient which is common for each country in the panel, because long and short-run coefficients are country-specific. The PMG estimator was introduced by Pesaran, Shin and Smith (1999), and it allows for long-run coefficients to be common for all countries in the panel. So, this means that the PMG estimator), restricts the long-run slope coefficients to be the same across countries but allows the short-run coefficients (including the speed of adjustment) and the regression intercept to be country-specific. We have estimated five models with different combination of explanatory variables. We have estimated five models because the models which includes a lot of different explanatory variables do not pass specification test (Hessian has become unstable or asymmetric). The results of our analisys for the PMG estimators are presented in Table 5.

The Hausman test reports the $\mathrm{p}$ value for Chi-Square statistic at $0.61,0.35,0.93$, 0.64 and 0.87 , respectively for all five models, which implies that the homogeneity restriction is not rejected jointly for all long-run parameters. This confirms that a PMG estimator is more efficient than MG estimator. For this reason, Table 5 contains only the PMG estimators. We compare all five models by log-likelihood criteria, and we conclude that model 1 is better than the other models. According to the log-likelihood criteria, model 1 is just slightly better than model 4. Here, we will apply the Akaike's information criterion and Bayesian information criterion which will enable us to choose the best model.

Table 5: Estimated long run coefficients using PMG ARDL model for evaluation of the existence of co-integration relationship between TFP and productivity drivers (in logs)

\begin{tabular}{|c|c|c|c|c|c|}
\hline Variables & Model 1 & Model 2 & Model 3 & Model 4 & Model 5 \\
\hline \multicolumn{6}{|c|}{ Long-run Coefficients } \\
\hline \multirow{2}{*}{ ICT } & $0.0950811 * * *$ & $0.1091575^{* * *}$ & & & $0.1244064 * * *$ \\
\hline & $(0.0266817)$ & $(0.0213162)$ & & & $(0.0149308)$ \\
\hline \multirow{2}{*}{$\mathrm{R} \& \mathrm{D}$} & $0.0841364 * *$ & $0.4772302 * * *$ & $0.5902807 * * *$ & $0.2346918 * * *$ & $0.5313717 * * *$ \\
\hline & $(0.047987)$ & $(0.053411)$ & $(0.0610128)$ & $(0.0504122)$ & $(0.0331552)$ \\
\hline \multirow{2}{*}{ FDI } & & & $0.0191521 * * *$ & & $0.0101428 * * *$ \\
\hline & & & $(0.0052104)$ & & $(0.0029771)$ \\
\hline \multirow{2}{*}{$\mathrm{h}$} & & & $-1.093551 * * *$ & $0.1753788^{* * *}$ & $-0.724348^{* * *}$ \\
\hline & & & $(0.1350851)$ & $(0.0391181)$ & $(0.069101)$ \\
\hline \multirow{2}{*}{ OPP } & & $-0.412328 * * *$ & $-0.4192759 * * *$ & & $-0.4600276^{* * * *}$ \\
\hline & & $(0.042809)$ & $(0.042383)$ & & $(0.0288861)$ \\
\hline \multirow{2}{*}{ ECT } & $-0.3982966 * * *$ & $-0.408068 * * *$ & $-0.2477289 * *$ & $-0.360839 * * *$ & $-0.2960148 * *$ \\
\hline & $(0.1150139)$ & $(0.1153099)$ & $(0.0958865)$ & $(0.1194723)$ & $(0.1292536)$ \\
\hline
\end{tabular}




\begin{tabular}{|c|c|c|c|c|c|}
\hline Variables & Model 1 & Model 2 & Model 3 & Model 4 & Model 5 \\
\hline \multicolumn{6}{|c|}{ Short-run Coefficients } \\
\hline \multirow{2}{*}{$\Delta \mathrm{ICT}$} & -0.0064955 & -0.0117654 & & & 0.0067605 \\
\hline & $(0.0309741)$ & $(0.0299594)$ & & & $(0.0377807)$ \\
\hline \multirow{2}{*}{$\Delta \mathrm{R} \& \mathrm{D}$} & -0.1140146 & -0.0179613 & -0.0509522 & -0.1747626 & 0.0613922 \\
\hline & $(0.1287712)$ & $(0.1335947)$ & $(0.1358471)$ & $(0.2982841)$ & $(0.1481448)$ \\
\hline \multirow{2}{*}{$\Delta \mathrm{FDI}$} & & & 0.0014513 & & 0.0076899 \\
\hline & & & $(0.0046736)$ & & $(0.0097311)$ \\
\hline \multirow{2}{*}{$\Delta \mathrm{h}$} & & & -0.0365738 & -0.3599339 & -0.1243105 \\
\hline & & & $(0.1968467)$ & $(0.2921474)$ & $(0.2787216)$ \\
\hline \multirow{2}{*}{$\Delta \mathrm{OPP}$} & & $0.2546442 * * *$ & 0.0548608 & & 0.050424 \\
\hline & & $(0.0914019)$. & $(0.1709838)$ & & $(0.2225295)$ \\
\hline \multirow{2}{*}{ Constant } & $0.7060294 * * *$ & $1.349571 * * *$ & $2.001414 *$ & $0.1241152 * * *$ & $2.078365 * *$ \\
\hline & $(0.2018922)$ & $(0.3925864)$ & $(0.7735208)$ & $(0.0444187)$ & $(0.9074986)$ \\
\hline Hausman test & $\begin{array}{c}\text { Prob }>\text { chi } 2= \\
0.61\end{array}$ & $\begin{array}{c}\text { Prob }>\text { chi } 2= \\
0.35\end{array}$ & $\begin{array}{c}\text { Prob }>\text { chi }^{2}= \\
0.9399\end{array}$ & $\begin{array}{c}\text { Prob }>\text { chi2 }= \\
0.64\end{array}$ & $\begin{array}{c}\text { Prob }>\mathrm{chi}^{2}= \\
0.87563\end{array}$ \\
\hline $\begin{array}{c}\text { Log } \\
\text { Likelihood }\end{array}$ & 464.9448 & 503.2095 & 511.6984 & 465.0472 & 536.9844 \\
\hline Obs. & 238 & 228 & 244 & 226 & 226 \\
\hline
\end{tabular}

Standard errors in parentheses; $* * * \mathrm{p}<0.01, * * \mathrm{p}<0.05, * \mathrm{p}<0.1$.

Source: Authors calculation

According to the Akaike's information criterion, the model 4 is more effective estimator. According to the Bayesian information criterion, the model 1 is more effective estimator. When we analyze the log-likelihood criteria, the Akaike's information criterion, and Bayesian information criterion, we conclude that model 1 is the most efficient estimator. Therefore, based on the Hausman test we accept the PMG estimator as relevant for our analysis, and we will base our conclusion on the PMG estimation of model 1. Detailed analysis of the Akaike's information criterion and Bayesian information criterion is in the appendix.

\section{Results and discussion}

The goal of our survey is twofold: firstly, to calculate the TFP for the $10 \mathrm{EU}$ countries by applying the two-step model, and secondly, we aim to investigate the existence of the longterm impact of productivity drivers on the TFP, for the selected countries, by using the cointegrating technique. In our research, we have used the most common explanatory variables like human capital, R\&D, ICT, FDI, and country trade openness, as main productivity drivers. Investigation of long term 
impact of productivity drivers on TFP, by standard econometric tools, requires that all time series have the same level of integration. In our case, some variables are stationary at the level, and some are stationary at the first difference. Therefore, the use of standard co-integration tests such as Pedroni, and Fisher Johansen are not allowed. When time series do not have the same level of integration, econometric theory suggests the application of the relatively new panel ARDL (Auto Regressive Distrubuted Lag) model. This model will provide a consistent and effective estimation of both long- and short -term effects, on the basis of panel data series with a different level of integration, lower than I (2), which includes a relatively large number of observation units and time. In our survey, we have estimated the three models with a different combination of explanatory variables for the PMG and MG estimators. We have chosen the PMG estimation of model 1 based on the Hausman test, the Akaike's information criterion, Bayesian information criterion, and log-likelihood criteria.

In the long run, $\mathrm{R} \& \mathrm{D}$, and ICT do have a positive and statistically significant impact on the TFP. The positive impact R\&D, and ICT on the TFP is in order with empiric literature. And reproducing these results with our methodology was very reassuring. The estimated coefficient for the R\&D is 0.0841 , which means that an increase of human capital by $1 \%$ will lead to increase of the TFP by $8.41 \%$. The increase of ICT by $1 \%$ will result in an increase of the TFP by $9.5 \%$. All variables in our target model are statistically significant at $5 \%$ (R\&D is statistically significant at $5 \%$, and ICT is statistically significant at $1 \%$ ).

The Error correction term (ECT), has to be negative and not lower than -2 in order to exist a long-run relationship between the variables of interest. For our target model the ECT is negative and statisticaly significant at $1 \%$, which proves existance of the long term relationship between our variables. The coefficient for the ECT is -0.39829 , which means that speed of adjustment to the long run equilibrium is almost $40 \%$.

\section{Conclusion}

This paper analyses TFP trends in thirteen selected EU countries for the period 1995 to 2016. Most of the analysed countries converge around the same level of the TFP. Also obtained results in this paper reveal the existence of a long-term relationship, i.e. cointegration between the TFP on one hand, and R\&D, and ICT, on the other hand, confirming the basic hypothesis that there is a long-term and statistically significant relationship i.e. cointegration between the above-mentioned variables. The results of our research are in order with the empiric literature, and reproducing these results with our methodology was very reassuring. Our survey confirms the fact that the strongest impact on the growth of the TFP has the ICT, 
which is emphasized as the most important driver of total factor productivity in selected EU countries. We have confirmed hypothesis of the direct impact of the R\&D on the TFP growth rate through enhancement of a firm's innovative potential. The ICT firms are very often considered to have the potential for innovations, which is in order with our results.

The importance of the results of the research is reflected in the identification of the most significant drivers of TFP growth, as well as in determining the magnitude of the impact of all TFP drivers. The results send a clear message to the governments of selected countries that in order to increase economic performance, a special focus needs to be placed on specific policies that encourage investment in R\&D and greater use of ICT. During the research, we faced a number of problems, such as poor availability of data and information related to this issue. Due to the aforementioned limitation, future research on this topic should include specific information about measurement of the technology gap (i.e. the distance between the TFP of the country analysed and that of the country with the highest level of efficiency), estimation of the indirect impact of R\&D on the TFP growth rate, which can be achieved by increasing the absorptive capacity of firms, and an estimate of the growth rate of TFP at the frontier (i.e. the TFP growth rate of the most efficient country).

\section{References}

Abramovitz, M. (1956) "Resource and output trends in the United States since 1870", An Econ Rev,Vol. 46, pp. 5-23.

Aghion, P., \& Howitt, P. (1992) "A model of growth through creative destruction", Econometrica, Vol. 60, pp. 323-351.

Aghion, P., \& Howitt, P. (1998) "Endogenous Growth Theory”, Cambridge MA: MIT Press.

Ark, B., Van, V, Chen., B, Colijn., K, Jäger., W., Overmeer., \& M.P, Timmer. (2013) "Recent Changes in Europe's Competitive Landscape and Medium-Term Perspectives: How the Sources of Demand and Supply are Shaping Up", Economic Papers 485, DG ECFIN: European Commission.

Autor, D. H., Katz, L.F., \& Kreuger, A. B. (1998) "Computing inequality: have computers changed the labour market", Q J Econ, Vol. 63, pp. 1169-1213.

Balcerzak, A. P, \& Pietrzak, M. B. (2016) "Dynamic Panel Analysis of Influence of Quality of Human Capital on Total Factor Productivity in Old European Union Member States," Chapters, in: Tomas Kliestik (ed.), 16th International Scientific Conference Globalization and Its Socio-Economic Consequences. University of Zilina, The Faculty of Operation and Economi, edition 1, volume 0, pages 96103, Institute of Economic Research. 
Balcerzak, A. P, \& Pietrzak, M. B. (2016a) Quality of Institutions and Total Factor Productivity in European Union. Statistics in Transition new series. 17. 497514. 10.21307/stattrans-2016-034.

Batini, N. Jackson, B. Nickel, S. (2000) Inflation Dynamics and Labour Share in the UK, Bank of England Discussion Paper No.2, ISSN: 1748-6203.

Berlemann, M., \& Wesselhöft, J. E. (2014) "Estimating aggregate capital stocks using the perpetual inventory method: New empirical evidence for 103 countries", Review of Economics, Vol. 65, No. 1, pp. 1-34.

Berman, E., Bound, J., \& Machin, S. (1998) "Implications of skilled-based technological change: international evidence", $Q J$ Econ, Vol. 113, pp. 1245-1279.

Borensztein, E. De Gregorio., \& J. Lee, J. W. (1998) "How does FDI affect economic growth", $J$ Int Econ, Vol. 45, pp. 115-135.

Burda, C.M., \& Severgnini, B. (2008). Solow Residuals without Capital Stocks. Berlin: Humboldt-Universität zu Berlin.

Comin, D. (2008) "Total Factor Productivity In The New Palgrave Dictionary of Economics", Edited by Steven Derlauf and Larry Blume, U.K: Palgrave Macmillan.

Cororaton, C. (2002) "Total Factor Productivity in the Philippines". Philippine Institute for Development Studies.

De Le Fuente, A., \& Doménech, R. (2006) "Human capital in growth regressions: How much difference does data quality make", Journal of the European Economic Association, Vol. 4, No.1, pp. 1-36.

Easterly, W., Levine, R. (2001) "It's Not Factor Accumulation: Stylized Facts and Growth Models", Working Paper No. 164, Central Bank of Chile, doi: 10.2139/ ssrn.269108.

Felipe, J. (1997) "Total Factor Productivity Growth in East Asia: A Critical Survey", Asian Development Bank.

Ganev, K. (2005a) "Can Educational Attainment Explain Total Factor Productivity? Growth Accounting Evidence from Seven Transition Countries for the Period 1991-2000" Journal of World Economic Review, Vol. 2, No. 1, pp. 1-23, doi: $10.2139 /$ ssrn.2025900.

Ganev, K. (2005b) "Measuring Total Factor Productivity: Growth Accounting for Bulgaria", Bulgarian National Bank Discussion Paper, No. 48/2005. doi: 10.2139/ssrn.2025902.

Gehringer, A., Martínez-Zarzoso, I., \& Nowak-Lehmann, D. F. (2014) "TFP estimation and productivity drivers in the European Union", Center for European, Governance and Economic Development Research Discussion Papers, Vol. 189.

Griliches, Z. (1980) "R\&D and the productivity slowdown", American Economic Review, Vol. 70, No. 2, pp. 343-348. 
Griliches, Z. (2007) " $R \& D$ and Productivity: The Econometric Evidence", Chicago: University of Chicago Press.

Grossman, G., \& Helpman, E. (1991) "Innovation and Growth in the Global Economy", Cambridge MA and London UK: MIT Press.

Griffith, R., Redding, S., \& Van Reenen, J, (2004), 'Mapping the two faces of R\&D: Productivity growth in a panel of OECD industries', The Review of Economics and Statistics", No 86 (4), pp. 883-895.

Harberger, A. C. (1988) "Perspectives on capital and technology in less-developed countries", Estudios de Economía, Vol. 15, No. 1, pp. 1-24.

Havik, K., Morrow, K., Röger, W., \& Turrini, A. (2008) "The EU-US total factor productivity gap: An industry perspective", European Economy - Economic Papers. European Commission.

Hernandez, J.A., \& Mauleon, I. (2003) “Estimating the Capital Stock”, Universidad de la Laguna \& Universidad de Las Palmas de Gran Canaria.

Kamps, C. (2006) "New estimates of government net capital stocks for 22 OECD countries 1960-2001", IMF Staff Papers, Vol. 53, No. 1, pp. 120-150.

Kyriacou, G. A. (1991) "Level and Growth Effects of Human Capital: A CrossCountry Study of the Convergence Hypothesis", Working Papers 91-26, C.V. Starr Center for Applied Economics, New York University.

Lipsey, R. G., \& Carlaw, K. (2001) "What does Total Factor Productivity measure", Study Paper Version 02.

Lucas, R. (1998) "On the mechanisms of economic development", $J$ Monet Econ, Vol. 22, pp. 3-42.

Nadiri, M. I., \& Prucha, I. R. (1996) "Estimation of the depreciation rate of physical and R\&D capital in the US total manufacturing sector", Economic Inquiry, Vol. 34, No. 1, pp. 43-56.

Nehru, V., \& Dhareshwar, A. (1993) "A new database on physical capital stock: sources, methodology and results", Revista de Análisis Económico, Vol. 8, No. 1, pp. 37-59.

Nicoletti, G. \& Scarpetta, S. (2003), "Regulation, Productivity and Growth: OECD Evidence", Economic Policy, 36, pp. 9-72.

Redding, S. (1996) "The low-skill, low-quality trap: strategic complementarities between human capital and R\&D”, Econ J, Vol. 106, pp. 458-470.

Pesaran, M. Hashem, Yongcheol Shin, and Ron P. Smith. (1997) "Pooled Estimation of Long-Run Relationships in Dynamic Heterogenous Panels", EconPapers, Retrieved on the date 20.11.2016. from: http://www.econ.cam.ac.uk/people/ emeritus/mhp1/jasaold.pdf.

Pesaran, M. Hashem, and Yongcheol Shin. (1999) "An Autoregressive Distributed Lag Modelling Approach to Cointegration Analysis", Econometric and 
Economic Theory in the $20^{\text {th }}$ Century: The Ragnar Frish Centennial Symposium, pp. 371-413, http://dx.doi.org/10.1017/CCOL0521633230.011.

Rivera-Batiz L.A., \& Romer, P. M. (1991) "Economic integration and economic growth", QJ Econ, Vol. 106, pp. 531-556.

Romer, P. M. (1988) "Capital accumulation in the theory of long run growth", RCER Working Papers, University of Rochester, Center for Economic Research.

Romer, P. M. (1990) “Endogenous technological change", J Polit Econ, Vol. 98, pp. 71-102.

Romer, P. M. (1986) "Increasing returns and long-run growth", J Polit Econ, Vol. 94, pp. 1002-1037.

Sahu, S. K., \& Narayanan, K. (2011) "Total Factor Productivity and Energy Intensity in Indian Manufacturing: A Cross-Sectional Study", International Journal of Energy Economics and Policy, Vol. 1, No. 2, pp. 47-58.

Schreyer, P. (2000) The contribution of information and communication technology to output growth: A study of the G7 countries. OECD Science, Technology and Industry Working Papers 2000/2.

Severgnini, B., \& Burda, M. C. (2010) "TFP Growth in Old and New Europe", Comparative Economic Studies, Vol. 51, No. 4, pp. 447-466.

Solow, R. (1956). A Contribution to the Theory of Economic Growth. Quarterly Journal of Economics Vol. 70, No. 1 Feb., pp. 65-94.

Solow, R. (1957). Technical Change and the Aggregate Production Function. Review of Economics and Statistics, 39, pp: 312-320.

Vanags, A., \& Bems, R. (2005) "Growth acceleration in the Baltic states: what can growth accounting tell us", BICEPS Research Reports, http://www.biceps.org/ en/publications/research-reports.html. (04.12.2018).

Welfe, W. (2007) "Gospodarka oparta na wiedzy (Knowledge-based Economy)", Warszawa: PWE.

Eurostat, https://ec.europa.eu/eurostat (02.04.2020).

International Monetary Fund, The World.Economic Outlook (WEO) database, https://www.imf.org/external/pubs/ft/weo/2018/02/weodata/index.aspx, (04.12.2018).

The Conference Board, http://www.conference-board.org/data/globaloutlook, (28.11.2018).

The World bank, "World Development Indicators", https://data.worldbank.org/, (30.11.2018). 


\title{
Pokretači ukupne faktorske produktivnosti u odabranim zemljama EU: kointegracijski pristup
}

\author{
Zoran Borović ${ }^{1}$, Mladen Rebićn ${ }^{2}$, Dalibor Tomaś ${ }^{3}$
}

\begin{abstract}
Sažetak
U ovom radu predstavit ćemo rezultate našeg istraživanja o TFP-u i njegovim glavnim pokretačima. U tu svrhu, naša se analiza temelji na uzorku od trinaest zemalja EU-a za razdoblje od 1995. do 2016. godine. U prvoj iteraciji procijenili smo TFP za odabrane zemlje. Glavni cilj ovog rada je utvrditi postojanje dugoročnog odnosa, tj. kointegracije između TFP-a i njegovih glavnih pokretača. Da bi to učinili, u drugoj iteraciji koristili smo relativno novi model ARDL (Autoregressive Distributed Lag) model koji su predložili Pesaran (1997) $i$ Pesaran $i$ Shin (1999). Dobiveni rezultati u ovom radu otkrivaju postojanje dugoročne veze, tj. kointegracija između TFP-a s jedne strane i istraživanja $i$ razvoja i ICT-a s druge strane, potvrđujući osnovnu hipotezu da postoji dugoročan $i$ statistički značajan odnos, tj. kointegracija između gore navedenih varijabli.
\end{abstract}

Ključne riječi: ekonomski rast, ukupna faktorska produktivnost, inovacije, KobDaglasova proizvodna funkcija, strane izravne investicije, istraživanje i razvoj, informatičke i komunikacione tehnologije

JEL klasifikacija: F20, F21, F23

${ }_{1}$ Docent, Ekonomski fakultet, Univerzitet u Banja Luci, Majke Jugovića 4, 78000 Banja Luka, BiH. Znanstveni interes: teorijska ekonomija. Tel.: +38751430 010; Fax: +38751430 053. E-mail: zoran.borovic@ef.unibl.org.

2 Izvanredni profesor, Ekonomski fakultet, Univerzitet u Istočnom Sarajevu, Alekse Šantića 3, 71420 Pale, BiH. Znanstveni interes: teorijska ekonomija. Tel.: +387 57226 651; Fax: +387 57226 188.E-mail: rebicmladen@yahoo.co.uk.

3 Viši asistent, Ekonomski fakultet, Univerzitet u Banja Luci, Majke Jugovića 4, 78000 Banja Luka, BiH. Znanstveni interes: teorijska ekonomija. Tel.: +38751430 010; Fax: +38751430 053.E-mail:dalibor.tomas@ef.unibl.org. 


\section{Appendices}

Table 6: The result of the unit root tests (in logs)

\begin{tabular}{|c|c|c|c|}
\hline Variable & Exogenous variables & Method & $\mathrm{p}$ Value \\
\hline $\mathrm{TFP}$ & trend & Im-Pesaran-Shin & 0.0380 \\
\hline $\mathrm{R} \& \mathrm{D}$ & trend & Im-Pesaran-Shin & 0.8572 \\
\hline$\Delta \mathrm{R} \& \mathrm{D}$ & trend & Im-Pesaran-Shin & 0.0000 \\
\hline $\mathrm{ICT}$ & trend & Im-Pesaran-Shin & 0.2356 \\
\hline$\Delta \mathrm{ICT}$ & trend & Im-Pesaran-Shin & 0.0000 \\
\hline FDI & trend & Im-Pesaran-Shin & 0.0000 \\
\hline $\mathrm{OPP}$ & trend & Im-Pesaran-Shin & 0.0311 \\
\hline $\mathrm{h}$ & trend & Im-Pesaran-Shin & 0.8638 \\
\hline$\Delta \mathrm{h}$ & trend & & 0.0000 \\
\hline
\end{tabular}

Table 7: The Akaike's information criterion, and Bayesian information criterion for model 1

\begin{tabular}{|c|c|c|c|c|c|c|}
\hline Model & Obs. & 11(null) & 11 (model) & df & AIC & BIC \\
\hline PMG & 238 & & 464.9448 & 6 & -916.6897 & -895.8561 \\
\hline
\end{tabular}

Table 8: The Akaike's information criterion, and Bayesian information criterion for model 4

\begin{tabular}{|c|c|c|c|c|c|c|}
\hline Model & Obs. & 11(null) & 11 (model) & df & AIC & BIC \\
\hline PMG & 226 & & 465.0472 & 8 & -918.0945 & -890.7302 \\
\hline
\end{tabular}


